\title{
Transforming dumps into gold mines. Experiences from Swedish case studies
}

Nils Johansson, Joakim Krook and Mats Eklund

\author{
Linköping University Post Print
}

\section{Tweet}

N.B.: When citing this work, cite the original article.

Original Publication:

Nils Johansson, Joakim Krook and Mats Eklund, Transforming dumps into gold mines. Experiences from Swedish case studies, 2012, Environmental Innovation and Societal Transitions, (5), 33-48.

http://dx.doi.org/10.1016/j.eist.2012.10.004

Copyright: Elsevier

http://www.elsevier.com/

Postprint available at: Linköping University Electronic Press

http://urn.kb.se/resolve?urn=urn:nbn:se:liu:diva- 85347 


\section{Transforming Dumps into Gold Mines. Experiences from}

Swedish Case Studies

Nils Johansson ${ }_{a}{ }^{*}$; Joakim Krook ${ }_{a}$ and Mats Eklund ${ }_{a}$.

*Corresponding author: Department of Management and Engineering, Environmental Technology and Management Linköping University, SE-581 83 Linköping, Sweden. nils.johansson@liu.se, +46(0)13285629.

${ }^{a}$ Department of Management and Engineering, Environmental Technology and Management Linköping University, SE-581 83 Linköping, Sweden. joakim.krook@liu.se, mats.eklund@liu.se. 


\begin{abstract}
This article discusses the transformation of landfills from dumps to an alchemist's dream-gold mines-by highlighting five Swedish case studies where the landfill has been extracted. It is shown that landfills are embedded in broader socio-technical systems, including technology, policies, culture, norms, markets, and networks. These artifacts have aligned into mutual dependencies under the notion that landfills are garbage dumps, which has entrapped the landfill in the prevailing "dump regime". At the present time there is a window of opportunity to escape the "dump regime." Dumps are being challenged by the circular economy, which has established instability in the regime. However, for landfills to transform into "gold mines" creative entrepreneurs with the capacity to understand the emergent properties of deposition - i.e. giving rise to a resource base - will be key. For further transformation, specialized mining actors, collaboration and further exogenous changes such as higher metal prices are necessary.
\end{abstract}

Key words: alchemy, escaping lock-in, landfill mining, resource policy, socio-technical transition, waste regimes. 


\section{Introduction}

Landfills are commonly defined as a site for the disposal of waste. Such a treatment method assumes that the waste simply has no value, i.e., it is useless and therefore buried and shielded from the economy. Accumulated waste, however, is not only worthless; it can even have a negative value and pose a serious threat to humans and the environment, including the leakage of hazardous substances (Baun and Christensen, 2004) and methane emissions (Bogner et al., 1995). Hence, the orphaned, abandoned and neglected waste "bites back" (Tenner, 1997) on the society that created it. Meanwhile, for some, especially birds and birdwatchers, landfills may be considered an important ecological oasis in the urban environment, sometimes more popular than city parks.

Increasingly, waste is defined as surplus material (Gourlay, 1992); a byproduct; material we have failed to use. From such a perspective, disposal is commonly regarded as a lost opportunity and a waste of resources. What is often forgotten in this context, however, is that the isolated events of deposition combined make a new potential resource base, which to some extent can be compared to traditional mines in terms of quality and quantity (Kapur and Graedel, 2006; Johansson et al., 2012). Research in industrial metabolism (e.g. Graedel et al., 2004) has shown how resources and metals in particular are extracted from the lithosphere, turned into products, consumed and then usually end up in landfills. In countries like Sweden, where incineration has largely replaced landfills, significant amounts of metals end up in ash, which is commonly landfilled (Kuo et al., 2007). However, landfills contain not only metals such as gold (Ongondo et al., 2011) like conventional mines but are also filled with plastic, wood, paper and other valuable resources.

The potential extraction of secondary minerals ${ }^{1}$ has been conceptualized through various mining concepts such as urban mining (Brunner and Rechberger, 2004), technospheric mining (Johansson et al., 2012) and waste mining (Ayres, 1999). However, these concepts focus on recovering metals from either traditional waste streams or all the stocks of secondary minerals including for example tailing ponds ${ }^{2}$. Landfill mining (Krook et al., 2012), on the other hand, focuses on landfills in isolation by excavating and recovering deposited waste. Hence, it revives what is buried by digging up a landfill and gives the waste a new chance. However, mining the technosphere and landfills in particular is not common practice in developed countries ${ }^{3}$ (Johansson et al., 2012) and typically surrounded by many uncertainties of economic (Fisher and Findlay, 1995), technical (Dickinson, 1995) and legal (US EPA, 1997) nature.

In evolutionary economics path dependency processes are usually observed, where traditional technology persists, like the VHS video recorder (Arthur, 1990), pesticide use (Wilson and Tisdell, 2001) and fossil fuel-based technologies (Unruh, 2000; Walker, 2000), even in the face of competition from potentially superior substitutes. Lock-in emerges when disciplines such as technology, markets, law, science, culture, and policy co-evolve in tandem and align into a regime (Dosi, 1982; Rip and Kemp, 1998; Geels, 2004). Such mutual dependencies establish stability around the system with an exclusion effect for dissenting innovations. Despite system inertia, new innovations can nevertheless emerge if exogenous changes at the macro level establish instability and tension in the existing regimes (Arthur, 1988; Cowan and Hulten, 1996; Freeman and Louçã, 2001).

\footnotetext{
${ }^{1}$ Minerals once already extracted, and therefore found not in the lithosphere but in the technosphere.

${ }^{2}$ For further discussion on mining concepts, see Johansson et al. (2012)

${ }^{3}$ Scavengers at landfill sites have probably been around ever since people started to deposit valuable resources (Rathje and Murphy, 1992).
} 
More recently, by studying conflicting regimes in the waste sector, waste, like technology, has proven to be a highly embedded, dynamic phenomenon (although with properties of inertia). For example, Zsuzsa Gille (2010) has showed how exogenous changes have pushed institutions' perceptions of waste over time and enlisted policy, technologies and economics into various waste regimes. Furthermore, Ruth Lane (2011) and Josh Lepawsky (2012) have demonstrated the obstacles in transforming the collection schemes by allowing the involvement of informal actors and implementing producer responsibility, respectively. Whether regimes can be applied to landfills and theoretically explain the origin of the uncertainties remains to be studied.

The point here is not to engage in a comprehensive historical analysis of landfills, since the aim is normative, or more precisely: to uncover a new "landfill regime" in which landfills, containing gold and other minerals, are not the end station for material but the starting point. In a sense, we are thereby approaching a classical alchemical experiment ${ }^{4}$, the Magnum opus, to understand how valueless material can be transformed into gold and other valuable commodities. However, no chemical experiments will be performed ${ }^{5}$. Instead, the aim of the article is to study the materiality of dumps, in order to provide knowledge on how to transform such valueless piles of junk into the alchemical dream, gold mines. This is done by reviewing five Swedish landfill mining (LFM) cases and analyzing how the variety of uncertainties typically surrounding such LFM projects was addressed. The outcome of the cases and why some projects were successful while others failed is discussed by analyzing the socio-technical nature of the system surrounding Swedish landfills. Key challenges and critical factors essential to transforming landfills into a new "landfill regime" are then identified.

\section{Method}

\subsection{SELECTION OF CASES}

Based on the definition of landfill mining, a typical case includes, at a minimum, excavation of a landfill and recovery of deposited resources. From this basis, five cases have been identified through snowball sampling and contact with authorities, experts and researchers. Cases were searched until the same cases kept recurring. All proposed cases were included in the study, except one where information collection was prevented by a lack of documentation and failure to contact possible respondents. Since two cases, Ringstorp and Stentippen are located in the same city, Helsingborg, these two cases are referred to in the article by the landfill name, while the other cases are referred to by location: Malmö, Strängnäs, Landskrona. The cases differ significantly in terms of main drivers, scale and time, as seen in Table 1. All landfills are owned and managed by the municipality or publicly owned waste companies.

\footnotetext{
${ }^{4}$ The art of transformation or of possibilities.

${ }^{5}$ The human imagination should be the prime matter targeted for transformation according to many nonlaboratory alchemists such as Mary Anne Atwood (Martin, 2001).
} 
Table 1. An overview of the case studies.

\begin{tabular}{|c|c|c|c|c|c|}
\hline & Malmö & Strängnäs & Helsingborg & Helsingborg & Landskrona \\
\hline Landfill & Lernacken & Kvitten & Ringstorp & Stentippen & Landskrona Landfill \\
\hline Driver & $\begin{array}{l}\text { Construction of the } \\
\varnothing \text { resund Bridge }\end{array}$ & $\begin{array}{l}\text { Difficulty in finding } \\
\text { locations for new landfill }\end{array}$ & $\begin{array}{l}\text { High levels of } \\
\text { leach water }\end{array}$ & City expansion & $\begin{array}{l}\text { Comply with the } \\
\text { landfill directive }\end{array}$ \\
\hline $\begin{array}{l}\text { Main } \\
\text { objective }\end{array}$ & Land reclamation & $\begin{array}{l}\text { Extend the capacity of the } \\
\text { landfill }\end{array}$ & Reduce leakage & $\begin{array}{l}\text { Land } \\
\text { reclamation }\end{array}$ & $\begin{array}{l}\text { Upgrade landfill } \\
\text { infrastructure }\end{array}$ \\
\hline Solution & Remediation & Resource recovery & Remediation & Remediation & Resource recovery \\
\hline Initiator & SVEDAB* & The Waste manager & Municipality & $\mathrm{NSR}^{* *}$ & The Waste manager \\
\hline Year & $1995-2000$ & $1988-2001$ & 2005-2006 & $2008-2010$ & $2000-2008$ \\
\hline $\begin{array}{l}\text { Excavated } \\
\text { volume }\end{array}$ & $\begin{array}{l}\text { Full scale: } 1,600,000 \\
\text { tons }\end{array}$ & Pilot studies: 20,000 tons & $\begin{array}{l}\text { Full scale: } 180,000 \\
\text { tons }\end{array}$ & $\begin{array}{l}\text { Full scale: } \\
340,000 \text { tons }\end{array}$ & $\begin{array}{l}800,000 \text { tons } \\
(2000 \text { tons })^{* * *}\end{array}$ \\
\hline
\end{tabular}

In general, the main objectives of the cases have been to remove the landfill or parts of it. All cases have been problem driven, where an identified problem has been the reason behind exhuming the landfills. This problem, i.e., the process of excavating the landfill, has then mainly been addressed in two crucially different ways: 1 ) by remediation, where the waste has simply been excavated and then moved to a more appropriate location, with some of the exhumed waste used as construction material; or 2) through resource recovery, where the waste has been excavated and then recovered in terms of metals recycled and combustible energy recovered. The scale of the projects differ, ranging from international affairs such as a bridge connection between two countries, with major financial power, or municipalities searching for new land to pilot studies initiated by innovative waste managers with limited budgets. The fact that the projects were implemented in varying time periods, from the 1980s to the present, should also be considered since the prevailing conditions, such as regulation and markets, have varied.

\subsection{DATA COLLECTION}

A review of landfill mining literature was initially done to guide the collection of information from the case studies. In this review ${ }^{6}$ six main types of barriers/challenges were identified as remaining to be addressed before landfills can be transformed into mines: Prospecting, Technology, Market, Regulation, Attitudes and Feasibility.

Research focusing on waste composition of landfills has shown, even within specific sites, large variations in physical and chemical characteristics as well as material composition (Cossu et al., 1996; Reith and Salerni, 1997). This makes prediction of the content and thus determination of valuable resources or hazardous components in the landfill difficult. Such a figuratively uncertain black box makes prospecting a key challenge. Previously reported case studies (e.g. Dickinson, 1995; Reeves and Murray, 1997; Zhao et al., 2007) have shown difficulties in sorting out the deposited waste into desired pure fractions. Few recycling agents are interested in accepting unsorted masses. The availability and performance of technology thus becomes another critical question. A further recurring conclusion from the reported cases is that the obtained quality of exhumed materials, soil excluded, is often not good enough to compete with virgin as well as secondary resources from traditional waste flows. The market for excavated deposited waste is thus uncertain, i.e., is there any demand for products from a landfill? What safety, administrative and regulatory requirements

\footnotetext{
${ }^{6}$ A more profound review may be found in "Landfill mining: a critical review of two decades of research" (Krook et al., 2012).
} 
landfill mining will involve, and how such demands will influence its viability, is also largely unclear, although authorities will most likely require an approved safety and health plan (Cossu et al., 1996; US EPA, 1997). For example, should re-deposited waste, once excavated, be interpreted as "new waste" and thus subject to waste tax and waste bans? Is permission required at all, and if so, which regulations are applicable? Although the previous cases had low impact on environment and health ${ }^{7}$, it remains unclear how the excavation is perceived by local residents. Overall, actors involved in the cases are hidden as well as the cultural values driving the mining operations. So, which actors need to be involved/committed to the process and what attitudes are featured in landfill mining? Some reported cases were considered cost-effective (e.g. van Passel et al., 2012) while others were not (e.g. Dickinson, 1995). These evaluations have however been site-specific, performed in different regions and under varying conditions and objectives. Hence, conclusive information on the feasibility of landfill mining operations is still lacking, i.e., is landfill mining profitable business?

Based on the six main types of barriers/challenges identified above, an interview guide was established framed by the overall question: How did the projects address these six typical challenges for landfill mining? General questions relating to drivers, initiator, actors and objectives were also asked. The interviews were conducted with those responsible for the projects, as decided by the actors themselves. In Landskrona and Strängnäs the responsible waste managers were interviewed. In Malmö, Stentippen and Ringstorp officials were singled out as project managers. The data for the case studies was gathered during 2010 by conducting semi-structured interviews and analyzing documents such as project proposals and project evaluations. The empirical result was categorized according to the main types of challenges and is presented in Chapter 3, explicitly in Table 2 and 3.

\subsection{ANALYSIS}

We first describe how the cases have managed the above uncertainties/challenges, on which the success of any LFM project rests (Baas et al., 2011). The result of the cases and the reason for success or failure are then analyzed, based on a framework suggested by Gille (2010), relating the sociotechnical conditions of the cases to the materiality of deposited waste. The outcome of this analysis is then used to identify the current regime surrounding landfills. From a multilevel perspective (Rip and Kemp et al., 1998, Kemp et al., 2001; Geels and Schot, 2007; Gille 2010), factors emphasizing individual and collaborative processes are then identified, which for the cases seem to be crucial to escape the regime and transform landfills into mines.

\section{Socio-technical landfills}

To make it more interesting, let's start at the wrong logical end: the outcome of the cases. The cases where the excavation was based on remediation and simply moved deposited masses to a more appropriate location seem to have been successfully implemented. In Malmö, the landfill was remediated and the $\varnothing$ resund Bridge has been stable since then. Stentippen in Helsingborg was excavated, the leakage stopped and the remaining pool may, if the city architect has his way, be used for outdoor concerts. The land where Ringstorp was located is currently being sold for housing. The purpose of remediation, removing contaminated soil so as to allow redevelopment of the land, was in all cases fulfilled. On the other hand, the cases which aimed to recycle, reuse and recover the masses from the landfill were never completed. In Strängnäs, only pilot studies were conducted, since the politicians did not want to finance large-scale resource recovery projects. The project in Landskrona met the same fate. Instead, the conventional method of capping and closing the landfills was chosen. Hence, the landfills in Landskrona and Strängnäs have been capped and waste for deposit sent to neighboring landfills.

\footnotetext{
${ }^{7}$ In terms of, for example, leaching of hazardous substances, poisonous gases, explosives and slope stability issues.
} 
The outcome of the different cases, i.e., the failure of the resource recovery projects in Landskrona and Strängnäs as well as the success of the remediation projects, may more or less be regarded as rational. Covering the landfill and sending small quantities of waste for deposition to a nearby landfill turned out to be a cheaper alternative than excavating the site, recovering the resources and bottom sealing the landfill. At the same time the need for landfill space had also drastically decreased due to landfill bans/taxes, which obviously reduced the need for additional capacity. The stakes were high and strong economic forces also supported the remediation operations; in Malmö a bilateral infrastructure project was at risk, and in Helsingborg the city's long-term expansion and groundwater supply was threatened. By analyzing how the cases managed the previously identified challenges and comparing conditions for resource recovery with remediation, the outcome and rationale can, however, be further explained by the socio-technical context of landfills.

\subsection{PROSPECTING}

Information about a landfill's composition is commonly absent, since waste has been deposited over time without any documentation. Waste has not been deposited in order to facilitate future extraction, but instead according to what has been considered to be effective and safe (OECD, 1994; European Council, 1999). The first step in the excavation of a landfill is thus to identify the landfill's interior.

In general, the cases used a combination of several methods to map the composition, as seen in Table 2. Qualitative methods, for example interviewing staff with long experience and analyzing historical documents such as old invoices or shipping documents provided an historical overview of the landfill structure. For example, in Landskrona old sludge pits could be identified through aerial photos, which thereby could be avoided during excavation. Historical flashbacks of the formal operation in landfills are, however, only half the story. People commonly take the liberty to unofficially deposit their own waste, if they discover open dumps. Therefore, to verify each case it became crucial to collect primary data of the current landfill interior through test pits (Malmö, Strängnäs and Landskrona) and/or well logging (Malmö, Landskrona, Ringstorp and Stentippen). For example, in Malmö, 2300 test pits measuring $2 \times 2 \times 4$ meters were excavated to map the interior. The distance between each test pit was about 10 meters. If nearby pits showed dissimilarities, boundaries between the masses were further investigated.

Table 2. An overview of how the landfill's interior was mapped, the permission status and conditions posed by authorities.

\begin{tabular}{|c|c|c|c|c|c|}
\hline & Malmö & Strängnäs & Ringstorp & Stentippen & Landskrona \\
\hline $\begin{array}{l}\text { Pre- } \\
\text { studies }\end{array}$ & $\begin{array}{l}\text {-Interviews. } \\
\text {-Examination of historical } \\
\text { documents. } \\
\text {-Sampling. } \\
\text {-Test pits }\end{array}$ & $\begin{array}{l}\text {-Interviews. } \\
\text {-Test pits. }\end{array}$ & -Sampling. & $\begin{array}{l}\text {-Interviews. } \\
\text {-Sampling. } \\
\text {-Test pits. }\end{array}$ & $\begin{array}{l}\text {-Interviews. } \\
\text {-Examination of historical } \\
\text { documents. } \\
\text {-Sampling. } \\
\text {-Test pits. }\end{array}$ \\
\hline Permission & Yes, for remediation & No & $\begin{array}{l}\text { Yes, for } \\
\text { remediation }\end{array}$ & $\begin{array}{l}\text { Yes, for } \\
\text { remediation }\end{array}$ & Yes, for landfill mining \\
\hline Conditions & Control program & $\begin{array}{l}\text { Methane } \\
\text { measurements }\end{array}$ & Control program & Control program & Control program \\
\hline
\end{tabular}

But even with the combination of methods, at best an overall understanding is reached where household, industrial waste, slag and sludge, i.e., different waste groups are positioned, as illustrated in Figure 1. 


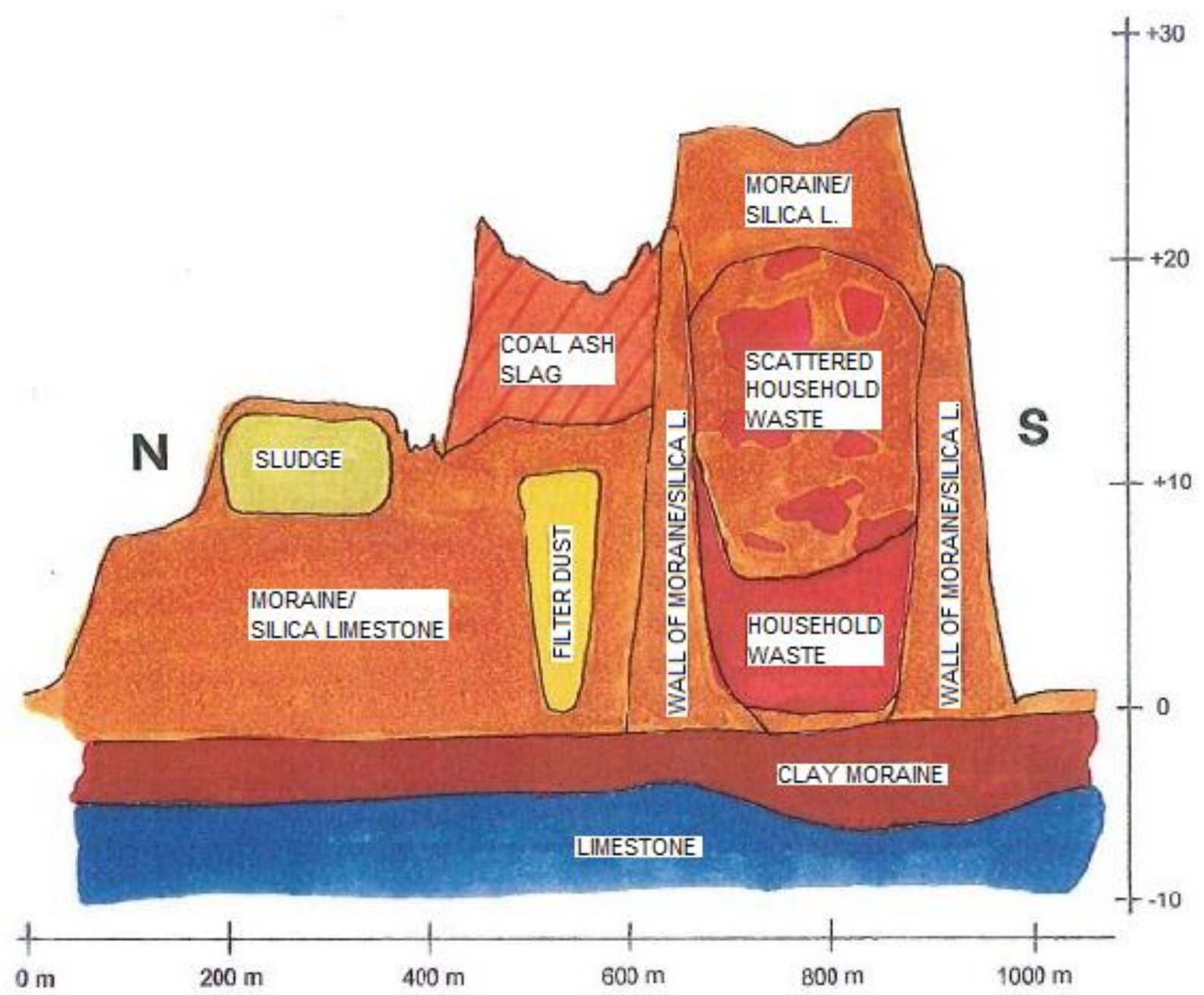

Figure 1. An overview of how different types of waste have been deposited in Lernacken (Malmö) was provided through conducting interviews, examining historical documents, sampling and test pits. Note that the height scale is greatly exaggerated (based on Möller, 1999).

Such a general image is likely to be highly adequate for remediating landfills since it is primarily the pollution levels that matter rather than the materials. In such cases, the mapping of material types is primarily important to ensure a safe excavation process. The same image, however, is inadequate for resource extraction in many ways. For example, detailed information on where valuable units, such as copper, iron, aluminum and timber, i.e., the ore, is located is not reported. This information is important both in order to estimate the potential profit and to determine where to dig.

In some remediation cases, an overview of the material composition may even prove to be redundant. For example, in Ringstorp, as seen in Table 2, sampling alone without any need for additional pre-studies proved to provide sufficient information to identify the composition of the landfill. Such sampling is commonly based on different physical and chemical speciation methods (Baun and Christensen, 2004), including primary metals dissipated from their original material in the primary form of free metal ions (McCarthy and Zachara, 1989). Speciation methods do not however provide a complete picture of the metal content in a landfill, since they exclude solid metals remaining in everything from car doors to cutlery and are therefore insufficient for resource extraction. In sum, the available methods for pre-studies seem to better match the needs of remediation than resource recovery. 


\subsection{TECHNOLOGY}

Excavators were used to exhume the waste in all case studies. Excavated quantities were then transported by wheel loaders to the intended destination. Depending on the approach (remediation or resource recovery), different separation techniques were selected, as shown in Table 3.

Table 3. An overview of separation methods, how the excavated waste was separated and then used in the different cases.

\begin{tabular}{|c|c|c|c|c|c|}
\hline & Malmö & Strängnäs & Ringstorp & Stentippen & Landskrona \\
\hline $\begin{array}{l}\text { Criteria for } \\
\text { separation }\end{array}$ & -Pollution level & $\begin{array}{l}\text {-Size } \\
\text {-Material type }\end{array}$ & -Pollution level & $\begin{array}{l}\text {-Pollution level } \\
\text {-Material type }\end{array}$ & $\begin{array}{l}\text {-Size } \\
\text {-Material type }\end{array}$ \\
\hline $\begin{array}{l}\text { Separation } \\
\text { Technology }\end{array}$ & -Sampling & $\begin{array}{l}\text {-Mobile screening } \\
\text { equipment } \\
\text {-Backhoe }\end{array}$ & -Sampling & $\begin{array}{l}\text {-Sampling } \\
\text {-Backhoe }\end{array}$ & $\begin{array}{l}\text {-Semi-mobile } \\
\text { separation }\end{array}$ \\
\hline Separation & $\begin{array}{l}\text { 1.High } \\
\text { 2.Medium } \\
\text { 3.Low }\end{array}$ & $\begin{array}{l}\text { 1.Large } \\
\text { 2.Medium } \\
\text { 3.Small } \\
\text { 4. Metal } \\
\text { 5.Concrete }\end{array}$ & $\begin{array}{l}\text { 1.High } \\
\text { 2.Medium } \\
\text { 3.Low }\end{array}$ & $\begin{array}{l}\text { 1.High } \\
\text { 2.Medium } \\
\text { 3.Low } \\
\text { 4.Paving }\end{array}$ & $\begin{array}{l}\text { 1.Large } \\
\text { 2.Small } \\
\text { 3.Metal }\end{array}$ \\
\hline Destination & $\begin{array}{l}\text { 1.Re-deposited } \\
\text { 2.Construction } \\
\text { material at the } \\
\text { landfill } \\
\text { 3.Construction } \\
\text { material for } \\
\text { roads }\end{array}$ & $\begin{array}{l}\text { 1.Incineration } \\
\text { 2.Construction } \\
\text { material at the landfill } \\
\text { 3.Compost \& } \\
\text { construction material } \\
\text { 4.Recycled } \\
\text { 5.Construction } \\
\text { material for roads }\end{array}$ & $\begin{array}{l}\text { 1.Re- } \\
\text { deposited } \\
\text { 2.Construction } \\
\text { Material at the } \\
\text { landfill } \\
\text { 3.Compost }\end{array}$ & $\begin{array}{l}\text { 1.Deposited as hazardous } \\
\text { waste } \\
\text { 2.Re-deposited } \\
\text { 3.Construction } \\
\text { material at the landfill } \\
\text { 4.Construction material } \\
\text { for roads }\end{array}$ & $\begin{array}{l}\text { 1.Re-deposited } \\
\text { 2.Compost } \\
\text { 3.Recycled }\end{array}$ \\
\hline
\end{tabular}

Separating the excavated waste is a relatively simple procedure for remediation; a gauge, as in Stentippen, can analyze pollution levels from which waste is sorted accordingly into different categories. The cases that aimed for further resource recovery primarily separated the waste by a screener according to the size of the waste. This technique proved successful, for example in Strängnäs, in achieving a soil fraction and reducing landfill volume, but far less efficient for obtaining homogeneous recyclables. The different size fractions became highly heterogenic and a backhoe was necessary to pick out certain materials, for example combustible material that was sent to incineration. The only parts that could be recycled without manual sorting, except soil, were ferrous metals with the help of a magnet.

\subsection{THE MARKET}

The possibilities for using the sorted waste varied between the cases and over time. The potential use of fractions after remediation is clearly defined, since the Swedish EPA has issued guidelines for assessment of contaminated soil (e.g. SEPA, 2009), which makes it easy to find specific applications. If the masses are relatively clean, they can be used for "sensitive land use" including housing or farming, a level that only the cover soil of Ringstorp (fraction number 3 ) passed, as seen in Table 3. Masses with a moderate pollution level, which parts of the masses in Malmö and Stentippen reached, can be used for "less sensitive land use" such as roads or industries. The masses must be deposited if these criteria are not fulfilled, which, however, means that they can be used as construction materials during landfill operation such as establishing embankments.

It becomes more difficult if the fractions have been separated by size or resource type. Although the market is currently converting to recirculation of materials, it is likely that goods from a landfill may be more difficult to accept for both recycling operators and consumers. The cases including resource recovery submitted only small quantities of metals and combustibles during the pilot studies. Thus, it is uncertain whether the recyclers and incinerators are willing or even have the capacity to receive larger quantities of excavated waste competing with often higher-quality material obtained from 
waste source separation programs. The cost of submitting combustibles is furthermore high ${ }^{8}$, and will rise if the combustibles are of poor quality, for example with high moisture content (Hammar, personal communication, 2010). Therefore, in Landskrona the combustibles were planned to be redeposited in anticipation of lower prices, as shown in Table 3. Whether this would have been consistent with the landfill ban on organic or burnable waste (SCS, 2001:512) is however uncertain. Applications for the excavated and separated resources such as organic combustibles are thus not easily determined. Consumers may furthermore be more likely to accept heating and electricity from incinerated deposited waste. It will probably be harder, however, to accept previously deposited material directly around us, such as cans or bottles, even if the contamination levels are approved.

\subsection{REGULATION}

Malmö, Stentippen and Ringstorp sought permission for remediation of contaminated land, as seen in Table 2. Ringstorp and Stentippen applied for a permit in accordance with the Ordinance on Activities Dangerous to the Environment and Protection of Health (SCS, 1998:899). Malmö applied however before the Swedish environmental legislation was combined in one code, and therefore two different permits and courts were included.

Strängnäs lacked permission. However, after the pilot test had been going on for a while the authorities in Strängnäs demanded that methane should be collected, as seen in Table 2. But measurements showed low levels and the requirement were never implemented. In Landskrona, permission for resource recovery was sought as a part of a larger application for operating the whole landfill according to the Environmental Code (SCS, 1998:808). Issues of interest to authorities during the permission process included: amounts, location, timeframes, technology, exhumation methods, sorting methods, and how to address, for example, odors, explosion, water, noise and dust. The Environmental Code also requires, through the knowledge rule, that the operator must know the landfill composition.

Regardless of time period and approach the permits have been granted in compliance with a control program focusing on the excavation process involving procedures for management of hazardous waste, systematic monitoring of air quality, safety plan, trained and well-equipped workers, and so on. Many of the case studies had existing permits for landfill operations, with conditions for example about odor, noise and leakage, which naturally were also in force for excavation of the landfill.

Hence, the process for remediation is clearly defined in current law (e.g. SCS, 1998:899) which makes the application process and demands on the operator relatively predictable. Excavation and recovery of deposited resources are, however, not mentioned in Swedish regulations and therefore legally uncertain $^{9}$.

\subsection{ATTITUDES}

All cases were problem-driven. The majority of cases did not even discuss the possibilities of recovering the deposited waste and chose instead to simply move the waste to a safer place. Two of the cases, Strängnäs and Landskrona, did however, as mentioned above, attempt to recover deposited waste. All projects were however operated by the initiators without any broader collaboration with actors from universities, governmental agencies or recycling operators. Consultants responsible for excavating, sampling and applying for permission were nevertheless involved. The locals were, to some degree, also concerned.

\footnotetext{
${ }^{8}$ 20-70 €/ton (PROFU, 2011).

${ }^{9}$ To simply dig up waste from a landfill probably does not require a permit. But authorization is required according to Swedish regulations (SCS, 1998:899), if for example on-site waste shall be sorted or hazardous waste handled.
} 
During the permit application consultations where all the interested parties are invited to express their opinions are a statutory requirement. In addition, a series of monthly meetings was held both in Ringstorp and Malmö with all stakeholders, including local residents as well as authorities. Every week local newspapers published news item and newsletters were sent to local residents to provide advance notice of work. The excavation in Malmö was also visited by school children as well as members of the European Parliament.

Despite openness and limited impact on the environment ${ }^{10}$, the projects were nevertheless met by protests. In Ringstorp, worried parents from a preschool nearby started a petition to postpone the planned excavation. During the excavation of Lernacken in Malmö, which was closely linked to the controversial construction of the Øresund Bridge, activists chained themselves to the machines and poured sugar into the tanks on excavators.

\subsection{FEASIBILITY}

The financial conditions have varied in the cases. Essentially, there were no direct revenues from any of the cases. During the pilot studies with resource recovery, however, revenues were received for metals, less construction material had to be purchased with resulting savings, and more landfill space was attained. For the cases based on remediation, the benefits were primary indirect; the abutment of Øresund Bridge could be built at Lernacken, improving the communication between Sweden and Denmark. The leakage from Stentippen was drastically reduced and the land at Ringstorp could be used for housing, thus fitting better into the urban environment. Major revenue may however be involved if the land is sold after completion of the projects. Thanks to high revenues from selling the land, Ringstorp in Helsingborg could show a profit (the only case to do so), although no fractions were sold, except soil.

The cost of the cases is very diverse, ranging from $4 € /$ ton to $35 € /$ ton. In the resource recovery cases, the costs of preliminary studies, bottom sealing, exhuming and recovering the waste were compared with the cost of final cover, monitoring over a 30-year period and transporting waste for deposit to an active landfill. You already know how it ended: capping proved more cost effective. Cost effectiveness, however, is never an objective criterion. Cases are evaluated against a typical standardization. Cases involving resource recovery were evaluated based on one actor's individual economic horizon ${ }^{11}$. The remediation cases, on the other hand, were evaluated from a socioeconomic perspective including societal benefits, for example, Malmö and the bridge connection between Sweden and Denmark. Hence, the remediation projects were allowed to be costly for a "greater cause". Furthermore, another example is the fraction that is too heterogeneous or polluted for any reasonable option after the excavated waste is sorted and therefore must be redeposited. Although there has been a landfill tax since 2000 (SCS, 1999:673), no cases were subject to taxes. Indeed, during remediation, the masses in need of re-deposition are deductable according to the Swedish Waste Tax Act (SCS, 1999:673). Resource recovery, on the other hand, is not mentioned as an exception in the Act, which makes cost estimation uncertain. For remediation operations, grants from the government (SCS, 2004:100) or foundations (SPIMFAB, 2011) are also available. Hence, such incentives and disincentives have most likely influenced the feasibility.

\footnotetext{
${ }^{10}$ In all cases, the emissions to the environment were essentially within the limits fixed by the authorities. The encountered problems were primarily technical or occupational in nature. For example, water complicated the excavation process in several cases. Ringstorp, however, which in contrast to the other cases was located inside the city with surrounding buildings, faced complaints from locals about noise, dust and traffic.

${ }^{11}$ For exceptions, see van der Zee (2004) and van Passel (2012)
} 


\section{The dump regime}

\subsection{THE LANDFILL IS STUCK IN A DUMP}

The process of excavating the landfill is in many ways similar for resource extraction and remediation; the same excavation equipment such as excavators is needed and similar problems such as protest are faced. The difference, which seems to determine the success, lies in the perception and management of the excavated waste. It is clear that remediation with redeposition of the waste and probably also capping the landfill are more in line with the current socio-technical system surrounding landfills in terms of technology, market, law, culture, science and policies which obviously facilitates the implementation. Resource recovery, on the other hand, is a mismatch (Freeman and Perez, 1988), thus an unconventional method, challenging the current socio-technical system surrounding the landfill.

What resource recovery is challenging more precisely is a socio-technical system based on landfills as a garbage dump. In Landskrona, for example, the managers applied for grants from the EU LIFE program $^{12}$ to develop technology for extracting resources from a landfill. The application was denied, however, since resource extraction and the perception of the deposited resources as an opportunity (a "mine") was considered to be contrary to EU principles of how landfills should be managed: landfills should be enclosed and secured. After all, the regulation body surrounding landfills is explicitly adapted to landfills as a dump, a linear end station for material, as seen in Table 4, including rules (e.g. European Council, 1999) based on the classification of landfills by their hazard level, leaching control, closure and after-care. The landfill tax (SCS, 1999:673) is another example, which was designed to reduce deposition rather than hinder resource extraction by taxing the masses in need of re-deposition.

Furthermore, landfill researchers have long underpinned the economic (e.g. Nelson et al., 1992) as well as environmental (e.g. Bogner et al., 1995) and health risks (e.g. Elliott et al., 2001; Baun and Christensen, 2004) associated with landfills. As demonstrated above, landfill technology and sampling equipment are also primarily designed to handle a garbage dump and for example deposit waste and control pollution levels. Simultaneously, it is easier to determine a market for the excavated waste if the masses are interpreted as a pollution problem. Finally, economic evaluations are typically based on certain standardization which fosters a particular trajectory (Unruh, 2002). For remediation projects, grants as well as deductions are available. Such projects are also evaluated from a wider perspective, including societal benefits, which changes the margins for expenses and revenues. In sum, the current socio-technical system surrounding landfills facilitates remediation or capping of landfills, since such operations accept the definition of landfills as a worthless dump, aiming solely to clean and move the dump to a more appropriate location or cover it, respectively.

\footnotetext{
12 "LIFE is the EU's financial instrument supporting environmental and nature conservation projects throughout the EU" (European Commission, 2011)
} 
Table 4. The material nature of the prevailing socio-technical system surrounding landfills, here referred to as the "dump regime", and a potential alternative; the "gold mine regime".

\begin{tabular}{llll}
\hline & The Dump Regime & The Gold Mine Regime \\
Material & Waste & Resources/Ores \\
Material Value & Worthless & Valuable \\
Material Flow & End station & Source \\
Material Culture & Oppress & Liberate \\
Material Policy & Linear & Circular \\
Material Technology & Encapsulate & Extract \\
Material Analysis & Sampling & Prospecting \\
$\begin{array}{l}\text { Economic, Social and } \\
\text { Environmental Impacts }\end{array}$ & Negative ${ }^{1}$ & Potentially positive ${ }^{2}$ \\
${ }^{1}$ Nelson et al., 1992; Bogner et al., 1995; Elliott et al., 2001; Baun and Christensen, 2004. &
\end{tabular}

Just like other systems, landfills too seem to be situated in a stable equilibrium, which cannot easily be changed since systems are embedded in wider socio-technical dimensions, termed "sociotechnical regimes" by Geels (2004). From such a perspective, the landfill and its content is thus entrapped in a "dump regime," where technology, markets, terminology, culture, laws, science and policies surrounding landfills have co-evolved and been enlisted into a dominant regime based on the perception of landfills as a garbage dump. Landfills are useless, literally nothing, and if they have any value it is primarily negative, as seen in Table 4, demonstrated for example by their negative impact on the property values of nearby residences (Nelson et al., 1992). Hence, a simple redefinition of the landfill and its materiality according to an alchemist's dream into a "gold mine regime," as visualized in Table 4, means that the entire socio-technical system established around the "dump regime" including, for example, its actors, relations, investments and knowledge, in short, its existence, is challenged. However, since such entrapment arises in most socio-technical systems (Rip and Kemp, 1998; Geels, 2004; Geels and Schot, 2010), it should furthermore mean that there are probably lessons to be learned from transition theory and other transformations subject to lock-in.

\subsection{THE DUMP REGIME IS CHALLENGED}

In order for transformations to take off, the prevailing "dump regime" has to become insufficient and unable to provide a satisfactory function (Arthur, 1988; Cowan and Hulten 1996; Freeman and Louçã, 2001). Such instability is often initiated by exogenous changes. For example, Zsuzsa Gille (2010) demonstrated that regime shifts in the Hungarian waste sector were preceded by economic reforms, policy change and the politicization of environmental issues.

Indeed, the "dump regime" has become unstable and deficient under previous norms; active, capped, as well as proposed landfills have come into question, according to the presented case studies. For example, the establishment of new landfills has become increasingly difficult such as in Strängnäs, where citizen resistance made it impossible to find a proper location for a new landfill. Even closed landfills have been contested. In Malmö and Ringstorp enclosed landfills stood in the way of progress and the development of infrastructure and urban expansion, respectively. In Stentippen, the pollution level in the leakage water was, despite being previously capped, above authorized levels. The management of active landfills has also been limited and complicated due to more stringent regulation. In Landskrona, the landfill did not meet the requirements of the Landfill Directive (European Council, 1999). Above all, regulations, such as landfill bans and taxes, and the implementation of the circular economy have made landfills generally redundant. For example in Sweden, deposition of municipal waste has decreased by $97 \%$ by weight since 1994 (ASWM, 2011a). In sum, these exogenous changes, beyond the control of landfill owners, have made deposition of 
waste and the landfill in the form of a dump insufficient, which has opened up an opportunity for change, a "window of opportunity" (Kingdon, 1995).

By analogy, the reported cases provides examples of how the waste sector responded to the tensions mentioned above in the current "dump regime". The common practice to regain stability has been like in Landskrona and Strängnäs, to close and cap landfills. In Sweden, over $70 \%$ of all landfills open in 1994 have today been capped (ASWM, 2008). In cases when capping and treatment of the effluents proved insufficient, like in Stentippen, remediation and removal of waste to secure landfills became the alternative solution to tackle the instability. These solutions are a small modification of an incremental nature. Capping in particular minimizes change to the system in its form of an end-ofpipe solution. The problem is simply covered, leaving existing infrastructure in place with a focus on the outflow from the system, i.e., treatment of emissions with add-on technologies. Remediation simply means that the waste is moved to a more appropriate landfill (dump) for safer deposition.

The incremental strategy is not surprising given that actors embedded in regimes see only the obvious and follow traditional paths (Nelson and Winter, 1982). However, innovation is possible within the given framework. For example, many Swedish cases of capping resulted in methane capture and recovery ${ }^{13}$, which Bill Clinton refers to as "gold mines" (Ragir and Oliveira, 2011). Clinton may be right; recovering methane from landfills could be a first step to transform the dump into a gold mine. Since this method is more in line with the current socio-technical system, policies, infrastructure and the landfill as such remains intact. Hence, it is primarily the effluents from the landfill that are targeted in this transformation rather than the socio-technical system surrounding the landfill and its mineral content. There are, however, as the case studies demonstrated, some radical exceptions, attracting little public attention, in which the current socio-technical system and the "dump regime" have been challenged.

\section{Transforming dumps into gold mines}

Although most actors tend to follow traditional paths, this is not true for all. Employees collect attractive deposited waste for their own needs and thus challenge the materiality of landfills (Reno, 2009). This self-organized, often spontaneous, approach seems to have no influence on either culture or landfill policy; on the contrary, it is against company policy and therefore hidden from "the boss." According to many researchers (e.g. Bass, 1990; Kingdon 1995) the idea of a transformation needs instead to be initiated by a key person in a position and with the ability to persuade policy makers, at a precise time when those in power are open to new ideas. Key individuals are also assumed to be particularly important in the initial phases of technical transformations, referred to as system builders (Hughes, 1979), by creating legitimacy, mobilizing resources and unifying diversity (Giddens 1984; Carlsson and Jacobsson, 1997).

In both Landskrona and Strängnäs individual leaders (in this case, waste managers) initiated the idea that the landfill could be extracted and deposited waste recycled as a way to meet the tensions in the "dump regime." In Strängnäs, the size of the current landfill began to reach limits specified in the permit. A political controversy arose regarding where the new landfill would be constructed, which opened up a possibility for innovation. The previous waste manager realized, as an alternative to establishing a new landfill, that the lifetime of the old landfill could be extended if the waste was excavated and recovered. In Landskrona, unlike many other owners, who capped and closed landfills in response to the landfill directive, the waste manager started to investigate extraction of deposited waste and sealing the bottom. Hence, the waste managers become spokespersons (Callon, 1986) ${ }^{14}$ for the landfills (in form of mines).

\footnotetext{
${ }^{13}$ Today, methane is captured in about 50 Swedish landfill sites (ASWM, 2011b).

${ }^{14}$ Callon uses the term "spokesmen".
} 
Although local decision-makers were persuaded to finance the projects, changes on the macro level including regulation, institutions and values were never reached, exemplified by the rejection of the EU application. One of the reasons may be the lack of cooperation with actors outside the initiators' own sector. In political theory, it is argued that advocacy coalitions (Sabatiers, 1988), i.e., networks with actors from different sectors, are crucial for changing institutions and policies. For example, Jacobsson and Bergek (2004) suggest that Germany's lead in renewable energy such as wind energy is mainly due to horizontal networks between different actors. These networks have challenged the carbon lock-in (Unruh, 2000) by creating legitimacy, aligning institutions and pushing for economic incentives. Hence, to achieve policy change, cross-sector networks, similar to the consortium in Belgium (Craps et al., 2011), should engage in politics, influence public opinion and demonstrate that landfills in the form of "mines" can solve wider policy concerns. For example, landfill mining can create jobs (Jones et al., 2012), reduce carbon emissions (Frändegård et al., 2012), prevent future leakage, postpone metal scarcity and by relying on anthropogenic stocks of metals increase the autonomy of governments.

Besides collaboration outside the sector, more cooperation inside the sector would have facilitated the transformation. For example, Ruth Lane (2011) has shown how the lack of sharing the available resources, between formal and informal actors in waste collection, has hampered effective recycling prior to dumping and the transition to the resource recovery regime. Such regressive forms of cooperation were also obvious in the transformation to the "gold mine regime." In these cases, it proved difficult to allocate the deposited resources fairly among involved actors and equitably distribute costs and revenues. In Landskrona, for example, the effect of the current model was that the major cost of combustibles was supposed to be solely borne by the initiator, while the revenue for produced heat would end up at the incinerator. Hence, the general rule of resource management; that resources should be shared between actors in partnership (Ostrom, 1990), seems also apply to waste management.

There have been no connections either between the cases and other reported landfill mining projects (e.g. Dickinson, 1995; Reeves and Murray, 1997; Zhao et al., 2007); these have been limited, isolated projects implemented by actors with other core business. There has thus been little transfer of knowledge and experience between cases and actors. Each case had to start from scratch in their efforts to reduce uncertainties and transform the landfill into a mine. Therefore, actors specialized in extracting waste, rather than burying waste probably need to emerge, i.e., division of labor, ready to invest in further experiments and learning processes. This would also make it possible for resource extraction from landfills to not only be an innovative solution to traditional management problems related to landfills such as lack of landfill space, which was the case in Strängnäs and Landskrona as well as other documented cases (e.g. Dickinson, 1995; Reeves and Murray, 1997), but the primary driving force. Furthermore, since the initiator of the mining cases in this study, the municipal waste manager, had other core activities and responsibilities under law, it may seem unfair to expect a sudden change of focus, efforts to mobilize actors and representation of the transformation at the macro level. Hence, specialized actors who are involved in more than single cases would probably be a more suitable spokesperson for landfills in the form of "mines".

Even if all these conditions are in place, including passionate individuals, advocacy coalitions, partnerships and specialized actors, it may nevertheless be problematic to overcome one specific obstacle: cultural attitudes. For someone living in the vicinity of a landfill, it can be difficult to grasp the benefits of reduced carbon dioxide emissions and increased metal supply, given that landfills are a typical NIMBY situation (Rasmussen, 1992). All the negative impact from deposition, i.e., smell, noise and transportation, which affects the locals, will revive if the waste is exhumed (Craps and Sips, 2011). Certainly, technical solutions may reduce these impacts, but never to a degree that avoids controversies. In fact, the cases with most transparency and participation, Ringstorp and Malmö, 
were also the cases that faced most opposition. As long as the waste is buried, the content seems almost irrelevant. However, when the deposited waste is excavated it suddenly becomes tangible, a potential risk, as it previously did not exist. Or, as one concerned parent put it in the local media, not to argue for remediation of the risk but to suspend the excavation of Ringstorp, "We do not know with certainty what is hidden in the masses. There may be toxins" (Bergström, 2007). Thus, it is not likely that the transformation will be initiated by social movements. However, to facilitate the operation, locals should be invited to participate in the management to represent the locals (Craps and Sips, 2011) and provide solutions (Lane et al., 2011), rather than simply be given the opportunity to express concerns.

\section{Conclusion}

The circular economy is currently challenging the societal function of the dumps, as the recirculation of waste makes landfills redundant. Such instability brings opportunities for new solutions to emerge. However, to initiate a radical transformation, exogenous changes can not only establish instability in the current regime, but must make the radical solution the most viable alternative. Otherwise, a solution that minimizes system change will scale up to restabilize the regime. For example, to stabilize the "dump regime" in Sweden, landfills are usually capped and monitored. Even cases where capping proves insufficient and the landfill need to be exhumed such as the one in Ringstorp will survive perfectly without resource extraction. Since the value of the land commonly exceeds the value of the content in a landfill (van der Zee et al., 2004), this could make extraction of resources redundant. Therefore, exogenous changes may be required, which not only destabilizes the "dump regime," but also makes the "gold mine regime" more attractive. For example, if the circular economy would align with even further resource scarcity, it would probably force us to not only look at waste but also landfills, the pyramids of waste, as an alternative resource base.

For the impatient, shortcuts are nevertheless possible if the emerging approach can be made more compatible with the old regime (von Bertalanffy, 1968). For example, resource extraction could be integrated with landfill remediation projects. After all, it is difficult to separate such remediation and resource extraction projects from each other; pure soil elements can be used as construction material in landfill remediation projects, while resource recovery projects would decrease the risk for leakage of heavy metals. Given the present waste management policy and legislation, it is even unlikely that resource recovery from landfills can be realized without any remediation and siterestoration efforts.

In countries with less strict and formal waste management than Sweden, landfills are often situated in parallel regimes. Landfills are simultaneously dumps and mines. Waste companies dump waste in the landfill, whereupon waste pickers collect deposited waste that is valuable. It would therefore be interesting to investigate how these "landfill regimes" can work side by side and where mining initiatives are not doomed to fail.

Finally, it is important to note that the extraction of resources from Swedish landfills did not fail because it was just another case of fool's gold. Landfills are made up of much more than the material content alone, i.e., a socio-technical system based on the notion that landfills are garbage dumps; the dump regime. Hence, for dumps to transform into goldmines, it is not the actual landfills that have to change, but the socio-technical system surrounding them. This suggests that the realization of the alchemist's dream, transforming worthless materials into gold, is not necessarily found in exoteric substances but in social dimensions. If our attitude to dumps can change, mines bursting with precious metals including iron, copper and gold are available. 


\section{Acknowledgements}

Financial support was provided by the Swedish Research Council for Environment, Agricultural Sciences and Spatial Planning, FORMAS. Santiago Mejía Dugand and Björn Wallsten contributed comments.

\section{References}

Arthur, B.W. (1988) Self-reinforcing mechanisms in economics. In: P. Anderson, K. Arrow, D. Pines (eds.) The Economy as an Evolving Complex System. New York: Addison Wesley, pp. 9-31.

Arthur, B.W. (1990) Positive feedbacks in the economy. Scientific American 262: 92-99.

Ayres, R. (1999) The second law, the fourth law, recycling, and limits to growth. Ecological Economics 29: 473-484.

ASWM (2008) Högst 90 deponier kvar efter 2008 [Maximum 90 landfills will remain open after 2008]. Association for Swedish Waste Management. Avfall \& Miljö 1:8.

ASWM (2011a) Svensk avfallshantering 2011 [Swedish waste management 2011]. Association for Swedish Waste Management. [online] http://www.avfallsverige.se/fileadmin/uploads/Rapporter/Utveckling/Rapporter 2011/SAH 1110 14 low.pdf [access: 2012-09-17].

ASWM (2011b) Uttag av gas/Gas capture. Association for Swedish Waste Management [online] http://www.avfallsverige.se/avfallshantering/deponering/deponigas/metanoxidation-paadeponier/gas-paa-deponi/uttag-av-gas/ [access: 2012-09-17].

Baas, L., J. Krook, M. Eklund and N. Svensson (2010) Industrial ecology looks at landfills from another perspective. Regional Development Dialogue 31 (2): 169-183.

Bass, B.M. (1990) From transactional to transformational leadership: learning to share the vision. Organizational Dynamics 18: 19-31.

Baun, D.L. and T.H. Christensen (2004) Speciation of heavy metals in landfill leachate: a review. Waste Management and Research 22: 3-23.

Bergström, T. (2007) Föräldrar vill vänta med sanering på Ringstorp [Parents want to wait with the remediation of Ringstorp]. Helsingborg Dagblad 2007-12-27 [online:] http://mobil.hd.se/helsingborg/2007/12/27/gstorp/ [access: 2012-09-17].

Bogner J., K. Spokas, E. Burton, R. Sweeney and V. Corona (1995) Landfills as atmospheric methane sources and sinks. Chemosphere 31 (9): 4119-4130.

Brunner, P.H. and H. Rechberger (2004) Practical Handbook of Material Flow Analysis. Boca Raton: Lewis Publishers.

Callon, M. (1986) Some Elements of a Sociology of Translation: Domestication of the Scallops and the Fishermen of St Brieuc Bay. In: J. Law (Ed) Power, Action and Belief: A New Sociology of Knowledge. London: Routledge \& Kegan Paul, pp. 196-233.

Carlsson, B. and S. Jacobsson (1997) In search of useful public policies - key lessons and issues for policy makers. In: B. Carlsson (ed.) Technological systems and industrial dynamics. Boston: Kluwer Academic.

Cossu, R., W. Hogland and E. Salerni (1996) Landfill mining in Europe and the USA. ISWA Tear Book: 107-114.

Cowan, R. and S. Hulten (1996) Escaping lock-in: The case of the electric vehicle. Technological Forecasting and Social Change 53: 61-79.

Craps, M. and K. Sips (2011) Enhanced Landfill Mining as a governance challenge: managing multiple actors, interests and perspectives. In P.T. Jones and Y. Tielemans (eds.) Enhanced Landfill Mining and the transition to Sustainable Materials Management, pp. 265-278. Houthalen- Helchteren: Haletra.

Dickinson, W. (1995) Landfill mining comes of age. Solid Waste Technologies 9: 42-47.

Dosi, G. (1982) Technological paradigms and technological trajectories : A suggested interpretation of the determinants and directions of technical change. Research Policy 11(3):147-162 
Elliott, P., D. Briggs, S. Morris, C. de Hoogh, C. Hurt, T.K. Jensen, I., Maitland, S. Richardson, J. Wakefield and L. Jarup (2001) Risk of adverse birth outcomes in populations living near landfill sites. British Medical J. 323: 363-368.

European Commission (2011) Welcome to LIFE. [online] http://ec.europa.eu/environment/life/ [access: 2012-09-17]

European Council (1999) Council Directive 1999/31/EC of 26 April 1999 on the landfill of waste.

Fisher, H. and D. Findlay (1995) Exploring the economics of mining landfills. World Wastes 38: 50-54.

Freeman, C. and C. Perez (1988) Structural crisis of adjustment, business cycles and investment behaviour. In: G. Dosi, C. Freeman, R. Nelson, G. Silverberg and L. Soete (eds.) Technical Change and Economic Theory. London: Pinter, pp. 38-66.

Freeman, C. and F. Louçã (2001) As Time Goes By: From the Industrial Revolutions to the Information Revolution. Oxford: Oxford University Press.

Frändegård, P., J. Krook, N. Svensson and M. Eklund (2012) A novel approach for environmental evaluation of landfill mining. J. of Cleaner Production, doi:10.1016/j.jclepro.2012.05.045.

Geels, F.W. (2004) From sectoral systems of innovation to socio-technical systems: insights about dynamics and change from sociology and institutional theory. Research Policy 33: 897-920.

Geels, F.W. and J.W. Schot (2007) Typology of sociotechnical transition pathways. Research Policy 36(3): 399-417.

Geels, F.W. and J.W. Schot (2010) The dynamics of transitions: A socio-technical perspective. In: J. Grin, J. Rotmans, J. Schot (eds.) Transitions to Sustainable Development: New Directions in the Study of Long Term Transformative Change, Oxon: Routledge, pp. 9-87.

Giddens, A. (1984) The constitution of society. Cambridge: Polity Press.

Gille, Z. (2010) Actor networks, modes of production, and waste regimes: reassembling the macrosocial. Environment \& Planning A, 42(5): 1049-1064.

Gourlay, K. (1992) World of Waste: Dilemmas of Industrial Development. London: Zed Books.

Graedel, T.E., D. van Beers, M. Bertram, K. Fuse, R.B. Gordon, A. Gritsinin, A. Kapur, R. Klee, R. Lifset, L. Memon, H. Rechberger, S. Spatari and D. Vexler (2004) The multilevel cycle of anthropogenic copper. Environmental Science and Technology 38: 1253-1261.

Hammar, M. (2010) Tekniska Verken, Linköping, Sweden. Personal Communication.

Hughes, T.P. (1979) The Electrification of America: The System Builders. Technology and Culture 20(1):124-161.

Jacobsson, S. and A. Bergek (2004) Transforming the energy sector: the evolution of technological systems in renewable energy technology. Industrial and Corporate Change 13 (5): 815-849.

Johansson, N., J. Krook, M. Eklund and B. Berglund (2012) An Integrated Review of Concepts for Mining the Technosphere: Towards a New Taxonomy. J. of Cleaner Production, doi:10.1016/j.jclepro.2012.04.007.

Jones, P. T., D. Geysen, Y. Tielemans, S. van Passel, Y. Pontikes, B. Blanpain, M. Quaghebeur, N. Hoekstra (2012) Enhanced Landfill Mining in view of multiple resource recovery: a critical review. J. of Cleaner Production, doi:10.1016/j.jclepro.2012.05.021.

Kapur, A. and T.E. Graedel (2006) Copper mines above and below the ground. Environmental Science and Technology 40: 3135-3141.

Kemp, R., A. Rip and J. Schot (2001) Constructing transition paths through the management of niches. In: Garud, R., Karnoe, P. (eds.) Path Dependence and Creation, pp. 269-299. Mahwah, NJ: Lawrence Erlbaum Associates Publishers.

Kingdon, J.W. (1995) Agendas, Alternatives, and Public Policies. HarperCollins, New York.

Krook, J., N. Svensson and M. Eklund (2012) Landfill mining: A critical review of two decades of research. Waste Management 32(3): 513-520.

Kuo, N.-W., H.-W. Ma, Y.-M. Yang, T.-Y. Hsiao and C.-M. Huang (2007) An investigation on the potential of metal recovery from the municipal waste incinerator in Taiwan. Waste Management 27 (11): 1673-1679. 
Lane, R. (2011) The waste commons in an emerging resource recovery waste regime: contesting property and value in Melbourne's hard rubbish collections. Geographical Research 49 (4): 395407.

Lane S. N., N. Odoni, C. Landström, S. Whatmore, N. Ward and S. Bradley (2011) Doing flood risk science differently: An experiment in radical scientific method. Transactions of the Institute of British Geographers 36(1): 1115-1136.

Lepawsky, J. (2012) Legal geographies of e-waste legislation in Canada and the US: Jurisdiction, responsibility and the taboo of production. Geoforum, doi: 10.1016/j.geoforum.2012.03.006

Martin, S. (2001) Alchemy and Alchemists. Harpenden, UK: Pocket Essentials.

McCarthy, J.F. and J.M. Zachara (1989) Subsurface transport of contaminants. Environmental Science and Technology 23: 496-502.

Möller, C. (1999) Slutrapport. Schakt och sanering, Lernacken [Final report. Excavation and remediation, Lernacken]. SVEDAB.

Nelson, A., J. Genereux and M. Genereux (1992) Price Effects of Landfills on House Values. Land Economics 68 (4): 359-365.

Nelson, R. and S.G Winter (1982) An Evolutionary Theory of Economic Change. Cambridge, MA: Belknap Press.

OECD (1994) Decision of the Council on the reduction of transfrontier movements of wastes. 27 May 1988 C(88)90/Final amendment on 28th-29th July 1994-C(94)152/FINAL.

Ongondo, F.O., I.D Williams and T.J. Cherrett (2011) How are WEEE doing? A global review of the management of electrical and electronic wastes. Waste Management 31: 714-730.

Ostrom, E. (1990) Governing the Commons. The Evolution of Institutions for Collective Action. New York: Cambridge University Press.

PROFU (2011) Mottagningsavgifter för avfallsförbränning 2011/ The gate fees for waste 2011. [online] http://www.profu.se/pdf/2011mottagningsavgifter Low.pdf [access: 2012-09-17].

Ragir, A. and J. Oliveira (2010) Clinton Sees 'Goldmine' in Capturing Methane to Fix Climate. Bloomberg 2011-06-01 [online] http://www.businessweek.com/news/2011-06-01/clinton-seesgoldmine-in-capturing-methane-to-fix-climate.html [access: 2012-09-17].

Rasmussen, T. H. (1992) Not In My Backyard: The Politics of Siting Prisons, Landfills, and Incinerators. State \& Local Government Review 24(3): 128-134.

Rathje, W. and C. Murphy (1992) Rubbish: The Archaeology of Garbage. New York: HarperCollins.

Reeves, T.S. and G.C. Murray (1997) Landfill mining - a tool for rural landfill management and closure. Proceedings of the Air and Waste Management. Association's 90th Annual Meeting and Exhibition. Toronto, Canada.

Reith, C.C. and E. Salerni (1997) Landfill mining for resource recovery. Proceedings of the Air and Waste Management Association's 90th Annual Meeting and Exhibition. Toronto, Canada.

Reno, J. (2009) Your trash is someone's treasure: the politics of value at a Michigan landfill. J. of Material Culture 14(1): 29-46

Rip, A. and R. Kemp (1998) Technological change. In: S. Rayner, E.L. Malone (eds.) Human Choice and Climate Change, vol. 2, pp. 327-399. Columbus, OH: Battelle Press.

Sabatier, P.A. (1988) An advocacy coalition framework of policy change and the role of policyoriented learning therein. Policy Sciences 21 (2-3): 129-168.

SCS (1998:808) Miljöbalken [Environmental Code]. Swedish Code of Statutes.

SCS (1998:899) Förordning om miljöfarlig verksamhet och hälsoskydd [Ordinance concerning environmentally hazardous activities]. Swedish Code of Statutes.

SCS (1999:673) Lag om skatt på avfall [Law on waste tax]. Swedish Code of Statutes.

SCS (2004:100) Förordning om avhjälpande av föroreningsskador och statsbidrag för sådant avhjälpande [Ordinance on remediation and government support for such remediation]. Swedish Code of Statutes.

SEPA (2009) Riktvärden för förorenad mark [Guidelines for contaminated land]. Swedish Environmental Protection Agency. Rapport 5976. 
SPIMFAB (2011) Oljebolagen sanerar nedlagda bensinstationer [The oil companies remediate abandoned gas stations]. SPI Miljösaneringsfond AB [online]

http://www.spimfab.se/fprw/files/SPIMFAB-informationsbroschyr-sept2011.pdf [access: 201209-17].

Tenner, E. (1997) Why Things Bite Back: Technology and the Revenge of Unintended Consequences. New York: Vintage Books.

Unruh, G. (2000) Understanding carbon lock-in. Energy Policy 28 (12): 817-830.

Unruh, G. (2002) Escaping carbon lock-in. Energy Policy 30 (4): 317-325.

US EPA (1997) Landfill reclamation. EPA 530-F-97-001, United States Environmental Protection Agency.

van der Zee, D.J., M.C. Achterkamp and B.J. de Visser (2004) Assessing the market opportunities of landfill mining. Waste Management 24: 795-804.

van Passel, S., M. Dubois, J. Eyckmans, S. de Gheldere, F. Ang., P.T. Jones and K. van Acker (2012) The economics of enhanced landfill mining: private and societal performance drivers. J. of Cleaner Production, doi:10.1016/j.jclepro.2012.03.024.

von Bertalanffy, L. (1968) General System Theory. New York: George Braziller.

Walker, W. (2000) Entrapment in large technology systems: institutional commitments and power relations. Research Policy 29: 833-846.

Wilson, C. and C. Tisdell (2001) Why farmers continue to use pesticides despite environmental, health and sustainability costs. Ecological Economics 39(3): 449-462.

Zhao, Y., L. Song, R. Huang, L. Song and X. Li (2007) Recycling of aged refuse from a closed landfill. Waste Management Research 25: 130-138. 